\title{
Sõnumeid rahvusvahelisest haridusvõrdlusest
}

\author{
Mati Heidmets \\ Tallinna Ülikool
}

Halapuu, V., Valk, A. (2013). Täiskasvanute oskused Eestis ja maailmas. PIAAC uuringu esmased tulemused. Tartu: Haridus- ja Teadusministeerium

Tire, G., Lepmann, T., Jukk, H., Puksand, H., Henno, I., Lindemann, K., Kitsing, M., Täht, K., Lorenz, B. (2013). PISA 2012, Eesti tulemused. Eesti 15-aastaste õpilaste teadmised ja oskused matemaatikas, funktsionaalses lugemises ja loodusteadustes. Tallinn: SA Innove.

2013. aasta sügisel ilmusid kokkuvõtted kahest rahvusvahelisest haridusvõrdlusest: PISAst ja PIAACst. Arvestades nende sarnast suunitlust (teadmiste taseme hindamine) ja olulisi kattumisi kasvõi Eestit puudutavates järeldustes, on põhjendatud ka nende koos käsitlemine.

PISA uuringu tulemused on Eestis saanud tavapäraselt laiaks aruteluaineks. Eelmisel sügisel avaldatud nn täiskasvanute PISA ehk PIAAC (Programme for the International Assessment of Adult Competencies) pole sellist huvi veel äratanud, kuigi vääriks seda. See on samuti OECD (Organisation for Economic Cooperation and Development) korraldatud uuring, kus võrreldakse täiskasvanute, st 16-65-aastaste inimeste infotöötlusoskusi. Uuring tehti aastatel 2011-2013, selles osales 24 riiki. PIAACga mõõdeti kolme liiki oskusi: funktsionaalset lugemisoskust, matemaatilist kirjaoskust ja probleemilahendusoskust tehnoloogiarikkas keskkonnas. Seejuures eeldati, et just eelnimetatud oskused on tänapäeva inimesele vajalikud, võimaldades edukalt osaleda tööturul, võtta osa elukestvast õppest, olla terve ning panustada aktiivse kodanikuna ühiskonnaellu.

Nii Eesti haridusuurijatele kui ka selle valdkonna praktikutele pakub PIAAC huvitavat andmestikku meie praeguse olukorra hindamiseks, aga ka edasiste sammude kavandamiseks. Lugemishuvi tekitamiseks osutan siinkohal mõningatele PIAACst koorunud mõtetele. 
Eesti inimeste funktsionaalne lugemisoskus ja matemaatiline kirjaoskus on maailma parimatega võrreldes igati konkurentsivõimelised, kuid meie inimeste probleemilahendusoskused tehnoloogiarikkas keskkonnas ja ka arvutikasutusoskused üldisemalt jäävad uuringus osalenud riikide võrdluses keskmisest allapoole, seda just vanemate ja huvitaval kombel ka kõrgharidusega inimeste puhul. Meie enesepilt tehnoloogiasõbralikust rahvast ei vasta päris tegelikkusele. Huvitav on see, et umbes kolmandik Eesti vastajatest eelistas probleemilahendamisel arvutit mitte kasutada, kuigi seda võimalust pakuti. Tundub, et paljude Eesti inimeste jaoks pole probleem mitte pelgalt oskustes, vaid ka väikeses eneseusalduses ja väheses julguses oma oskusi kasutada.

Vaadates erineva haridustaustaga täiskasvanute oskusi, selgub, et meie põhi- ja keskharidusega noorte funktsionaalne lugemisoskus ja matemaatiline kirjaoskus on uuritud riikide keskmisest tasemest parem, samas kõrgharidusega noorte funktsionaalne lugemisoskus ja matemaatiline kirjaoskus on osalenud riikidega samal tasemel. Keskmisest jäävad maha kõik meie keskealiste ja vanemate kõrgharidusega inimeste uuritud oskused. Teisisõnu, nõukogudeaegne hariduspagas paneb meie eakama põlvkonna teiste riikide samaealistega võrreldes veidi kehvemasse olukorda.

Asjaolu, et meie riigisisesed erinevused teadmistes on PIAAC kohaselt väikesed, on laias plaanis positiivne. Eestis on suhteliselt vähe nii väga kehvade kui ka väga heade oskustega inimesi, väikesed on ka soolised ja hariduslikud erinevused. Nagu teistes põhjamaades, mõjutab vanemate haridustase täiskasvanute oskusi ka siinmail suhteliselt vähe. See räägib Eesti sümpaatselt võrdsetest haridusvõimalustest. Ühiskonnas võrdlemisi ühtlaselt jaotunud tarkuse taustal tahaksid ehk meie (niigi vähesed) tipud sisukamat erikohtlemist.

Mõtlemisainet annab meie õpetajaskonna (kõrgharidusega ja õpetajakoolituse õppekava läbinud vastajate) võrdlus teiste uuringus osalenutega. Osutub, et keskmiselt on õpetajakoolituse lõpetajad teistest kõrgharidusega täiskasvanutest veidi halvemate (!) tulemustega. Näiteks on matemaatilise kirjaoskuse puhul peaaegu pooltes osalenud riikides õpetajakoolituse lõpetanutel tulemused halvemad kui teistel kõrgharidusega vastajatel. Seejuures on Eestis lõhe õpetajakoolituse ja teiste erialade lõpetajate vahel üks suurimaid, õpetajate kahjuks. Tehnoloogiarikkas keskkonnas probleemilahendusoskused on vaid veerandil Eesti õpetajatest heal või väga heal tasemel, mis jääb oluliselt alla osalenud riikide keskmisele. Tundub, et õpetajate ajalooliselt tugev positsioon Eesti haritlaskonnas kipub käest libisema. 
PIAAC võrdles ka õpetajate palka. Uuritud riikides oli õpetajate palk keskmiselt $12 \%$ kõrgem riigi keskmisest palgast. Eestis seevastu jäi õpetajate palk sellesama $12 \%$ võrra riigi keskmisele alla. Just Eestis (koos Venemaaga) oli õpetajate palga suhe riigi keskmisesse palka kõige enam õpetajate kahjuks. See on teema, kus ponnistustest hoolimata on veel vara hõisata. Kuigi Eesti õpetajaskonna teadmiste tase pole kõrgharidusega töötajate seltskonnas just väljapaistev ning ka palk jääb alla riigi keskmisele, pole see ometi takistanud meie õpetajatel tegemast väga tulemuslikku tööd.

Eesti õpetajate töö tulemustest räägib PISA (Programme for International Student Assessment) uuring. See on samuti OECD läbiviidav ning maailma suurim ja tuntuim haridusuuring. Iga kolme aasta järel mõõdetakse 15-aastaste õpilaste teadmisi ja oskusi kolmes valdkonnas: matemaatikas, funktsionaalses lugemises ja loodusteadustes. SA Innove koostatud kokkuvõte pakub meile kompaktset ja hästi loetavat sissevaadet nii viimase uuringu tulemustesse kui ka Eesti asendisse muu maailma taustal. PISA 2012. aasta uuringus osales kokku 65 riiki, sh 34 OECD liikmesriiki ja 31 partnerriiki. Valim koosnes 510000 õpilasest, igaüks sooritas umbes kahetunnise kirjaliku testi. 32 riigis (k.a Eestis) lahendas osa õpilastest peale testi ka elektroonilisi ülesandeid kolmes valdkonnas: probleemilahendus, matemaatika ja lugemine. Lisaks täitsid õpilased taustaküsimustiku, milleks kulus ca 40 minutit. Küsimustikuga uuriti õpilaste sotsiaalmajanduslikku olukorda, rahulolu kooliga jne.

Nagu teada, tõi viimane PISA Eestile mitmeid positiivseid sõnumeid. Eesti õpilased kuuluvad oma teadmiste poolest maailma absoluutsesse tippu. Vaid kolm OECD liikmesriiki (Korea, Jaapan, Šveits) ületavad statistilises mõttes Eesti tulemust. 2009. aastaga võrreldes on Eesti oma positsiooni riikide edetabelis märgatavalt parandanud. Toona jäime tahapoole kümnest OECD riigist. Lisaks võib praeguse uuringu põhjal täheldada mitmeid positiivseid suundumusi: matemaatikas on poisid tüdrukutele järele jõudnud ning isegi veidi ette läinud, õpilase sotsiaalmajanduslik taust mõjutab Eesti koolilaste tulemusi jätkuvalt vähem kui enamikus teistes riikides, vene koolide tulemused on hüppeliselt paranenud.

Kindlasti ei paku ei PIAAC ega PISA lõplikku tõde. Neist leiab hulganisti argumenteeritud osutusi, tõenduspõhiseid järeldusi, põnevaid vihjeid. Üritades üldistada Eesti kohta mõlemast uuringust saabunud sõnumeid, julgeksin välja pakkuda kaks järeldust.

Esiteks, Eesti haridus on parem, kui see meile seestpoolt vaadates tundub. Sellest johtuvalt ei vaja Eesti haridus revolutsioone ega kardinaalseid 
ümberkorraldusi. Eesti haridus vajab täpselt fookustatud süste, mis aitaksid laiendada ajale jalgu jäänud pudelikaelu. Suure süstlaga tuleb vähendada töökoormust, seda nii õpetajatel kui ka õpilastel. Tõsist süsti ootab ka kõik see, mis on seotud meie inimeste enesekohaste ja sotsiaalsete oskustega. PIAAC osutab, et märkimisväärset osa Eesti täiskasvanutest iseloomustab väike eneseusaldus ja vähene julgus oma oskusi kasutada. PISA lisab, et meie õpilased on sihikindlad, aga suhteliselt madala enesehinnanguga. Mis iganes ajaloolistel põhjustel eestlase hinge pugenud ebakindlusega tuleb hakkama saada, vähemalt ei tohiks seda järgmistele põlvkondadele liiga innukalt edasi anda.

Teiseks, meie väga hea hariduse jätkusuutlikkuse võti on õpetaja. Ja siin paistab mõlemast raportist Eesti jaoks ohutuli. Kuigi Eesti ülekoormatud ja alamakstud õpetaja teeb ikka veel maailma parimat tööd, saab see tulla vaid tema tervise, pereelu ja hingerahu arvelt. Selline asjakorraldus ei ole jätkusuutlik. Eesti järgmine rahvuslik suurinvesteering tuleb teha Eesti õpetajasse. Siis on lootust, et me võime ka järgmistele OECD võrdlustele uhke ja enesekindla pilguga otsa vaadata. 